\title{
A DIVERSIDADE DE NOMENCLATURAS EMPREGADAS PARA DESIGNAR PROPOSTAS PEDAGÓGICAS NÃO-TRADICIONAIS: Uma abordagem sobre Escolas Inovadoras, Escolas Reflexivas, Escolas Integrais e Escolas Democráticas
}

\author{
Maiara Ariele Pedersen*, Ana Maria Falcão de Aragão.
}

\begin{abstract}
Resumo
A fim de compreender os processos de transformação e mudança da escola atualmente, esta pesquisa problematiza o campo em que se situa a compreensão da diversidade de nomenclaturas empregadas para designar propostas pedagógicas não-tradicionais. Diante disto, utilizando como procedimento a pesquisa bibliográfica, o presente projeto de iniciação científica teve como objetivo identificar, descrever e analisar nomenclaturas empregadas para designar propostas pedagógicas não-tradicionais, como: Escolas Inovadoras, Escolas Democráticas, Escolas Reflexivas e Escolas Integrais. Para tal, fez-se necessário conhecer os caminhos pelos quais percorreram seus estudos, e com isso enfatizar os conceitos apresentados nas referidas definições buscando apontar semelhanças e diferenças. Por meio delas, podemos perceber a educação sob uma nova perspectiva, com uma visão mais ampla para além dos objetivos apenas de transmissão de conteúdos atribuídos comumente à escola tradicional, bem como compreender que o uso de determinada nomenclatura é cheio de intenções e significados, que compreende relações de poder e de espaço, e assim demarcar as implicações na escolha e no uso de determinado termo.
\end{abstract}

\section{Palavras-chave:}

Propostas Pedagógicas não-tradicionais, Escolas Inovadoras, Escolas Democráticas, Escolas Reflexivas, Escolas Integrais.

\section{Introdução}

Como parte de uma pesquisa maior sobre os modelos escolares não tradicionais, este trabalho dedicou-se a contribuir para o mapeamento do campo conceitual, investigando quatro nomenclaturas comumente empregadas para designar propostas pedagógicas que rompem com aspectos da escola tradicional: escolas inovadoras, escolas democráticas, escolas reflexivas e escolas integrais. Por meio de pesquisa bibliográfica, esta pesquisa se propôs a localizar autores de referência que utilizam os termos, para identificar princípios, teorias e práticas que estão associados a cada categoria, bem como apontar convergências e divergências entre elas.

\section{Resultados e Discussão}

Como aponta Barrera (2016), há um movimento por renovação educacional em curso no Brasil. O denominador comum entre os atores e as propostas que buscam tal renovação é a insatisfação com o modelo tradicional de escola. Todavia, um olhar mais cauteloso mostra que não se trata de um movimento homogêneo em seus valores e em suas prioridades; há diversidade de visões sobre educação, que se reflete em diferentes propostas. Não há um modelo consensual que possa simplesmente substituir a escola tradicional; portanto, quando entra em discussão as mudanças pelas quais a escola precisa passar, é preciso indagar: mudar o quê, para o quê, em nome de quê, e de que modo? Esta pesquisa buscou contribuir para o adensamento teórico da discussão, trazendo um exame de quatro termos comumente empregados para designar propostas alternativas ao modelo escolar tradicional. Como forma de propor uma conclusão possível, apresento, como síntese das lições de pesquisa, os principais elementos que permitem identificar, descrever e analisar as chamadas escolas inovadoras, escolas democráticas, escolas reflexivas e escolas integrais, e que conceitos são apresentados nas referidas definições, buscando apontar as semelhanças e diferenças. O primeiro dos termos analisados, escolas inovadoras, não pode ser considerado, a rigor, uma perspectiva própria; é, antes, uma categoria genérica para indicar a intenção deliberada de diferenciar o que é feito em tais instituições do conjunto de práticas tradicionais da escola. Esta categoria não está vinculada a uma teoria específica ou a uma visão própria de educação; é reivindicada tanto por propostas de cunho mais progressista, voltadas para a formação de cidadãos críticos, quanto por aquelas de interesse mercadológico, que buscam um diferencial pela adoção de tecnologias de última geração, por exemplo. O segundo, escolas democráticas, está ligado a uma proposta com raízes históricas e conceituais mais claras e identificáveis. As ideias sobre a relação entre a escola e a democracia remontam a Dewey, no começo do século XX; o termo "escola democrática" se consagrou décadas mais tarde, com experiências concretas como a Escola Hadera, em Israel, e condensou um movimento internacional que reúne escolas cuja característica distintiva é participação dos estudantes na tomada de decisões sobre o funcionamento da escola e sobre o currículo. $O$ termo escolas reflexivas surge a partir de uma proposta acadêmica. Deriva do conceito de reflexividade, caro ao campo de formação de professores, e representa a aplicação desses princípios a toda a instituição escolar como forma de produzir inovações, estimular o envolvimento de toda a comunidade escolar na elaboração do projeto pedagógico e propiciar espaços privilegiados de formação docente. Por fim, escolas integrais é um termo que hoje faz parte de diversos projetos e políticas públicas em educação, mas muitas vezes unicamente pelo aspecto do tempo de jornada estendido. Todavia, como proposta pedagógica, carrega a ideia de que a escolas não tem apenas a incumbência do desenvolvimento intelectual, mas também de outras dimensões e potencialidades do sujeito, e para isso deve proporcionar atividades e espaços diferenciados, além do conteúdo escolar. 